\title{
Matthew Arnold (1822-1888) - prekursor pedagogiki porównawczej w XIX-wiecznej Anglii oraz jego poglądy na edukację
}

\begin{abstract}
Matthew Arnold (1822-1888) - the Precursor of Comparative Education in $19^{\text {th }}$ Century England and His Views on Education

The aim of the article is to present the achievements of Matthew Arnold's in the development of European comparative education and to show his views on the changes in education in $19^{\text {th }}$ century England against the background of other European countries. In the works on comparative education, a French writer Marc-Antoine Jullien de Paris (1775-1848) is regarded as one of precursors of this scientific field (currently treated as a pedagogical subdiscipline), however, as also emphasized by Józef Miąso, the British comparativists: Matthew Arnold, Thomas Darlington and Robert Morant have significantly contributed to the development of European comparative education ${ }^{1}$. The achievements of British educators, sociologists and historians in this area are underestimated and almost unknown in Poland.

The development of English educational system in $19^{\text {th }}$ century was different in many ways from other educational systems in continental Europe, so that the works of English comparativists, such as Matthew Arnold are unique and very important for better understanding of the historical development of comparative research methodology and also the specifics of English schools system.

The article also proves that comparative education is a very important field of scientific research and played major role in planning the reforms of educational systems in many countries mainly in XIX and XX century. M. Arnold's analyses could be still valid in XXI century.

The study used the method of documental analysis, original Matthew Arnold's works in the field of education and English-language scientific publications dealing with his achievements in the field of popularizing comparative studies. A new overview of M. Arnold's achievement will ensure the use of sociological analyzes.
\end{abstract}

Keywords: comparative education, Matthew Arnold, inspector of schools, European comparativists, English school system

1 J. Miąso, Szkolnictwo w XIX-wiecznej Europie i początki pedagogiki porównawczej w Anglii, „Rozprawy z Dziejów Oświaty” 2009, t. XLVI, s. 85-146. 


\section{Wprowadzenie}

Historyczny rozwój pedagogiki porównawczej, a przede wszystkim wkład brytyjskich komparatystów w rozwój tego obszaru badań, jest słabo znany we współczesnej polskiej literaturze pedagogicznej. Obecnie dominuje bowiem socjologiczne podejście do analiz komparatystycznych. Uprawianie pedagogiki porównawczej w ścisłym powiązaniu z historią wychowania, którego zwolennikiem był Michael E. Sadler - właściwy twórca brytyjskiej komparatystyki, a które propagował w Polsce od lat 60. XX wieku Bogdan Nawroczyński, jest aktualnie bardzo mało popularne. $\mathrm{Z}$ tego też powodu polskiemu czytelnikowi interesującemu się pedagogiką porównawczą mało znane są dokonania XIX -wiecznych komparatystów brytyjskich z Matthew Arnoldem na czele. Zapewne wynika to z faktu, że sam M. Arnold - syn słynnego reformatora Rugby School Thomasa Arnolda - bardziej znany jest w polskiej literaturze naukowej jako wybitny poeta, krytyk literacki i społeczny epoki wiktoriańskiej aniżeli komparatysta edukacyjny.

W polskiej literaturze naukowej o dokonaniach M. Arnolda w obszarze pedagogiki porównawczej pisali jedynie Józef Miąso $^{2}$ oraz Agnieszka Gromkowska-Melosik³ . J. Miąso w obszernym opracowaniu z historii edukacji ukazał rozwój szkolnictwa w XIX-wiecznej Europie oraz początki badań komparatystycznych w Anglii. Wskazał również, że znaczący wkład brytyjskich pedagogów, historyków oraz socjologów w rozwój pedagogiki porównawczej jest w polskiej literaturze słabo znany, a dorobek tak wybitnych komparatystów, jak M. Arnold, Thomas Darlington ${ }^{4}$ i Robert Morant ${ }^{5}$ niekiedy całkowicie pomija się przy analizach historycznego rozwoju komparatysty$\mathrm{ki}^{6}$. Z kolei A. Gromkowska-Melosik, reprezentująca socjologiczny nurt badań we współczesnej polskiej pedagogice porównawczej, poddając analizie problem elitarnego szkolnictwa średniego w Anglii, odwołała się do dokonań M. Arnolda ${ }^{7}$, ale sięgając

2 Ibidem.

${ }^{3}$ A. Gromkowska-Melosik, Elitarne szkolnictwa średnie. Między reprodukcja społeczno-kulturowa a ruchliwościa konkurencyjną, Wydawnictwo Naukowe UAM, Poznań 2015, s. 71.

${ }_{4}^{4}$ Thomas Darlington (1864-1908) - uczony, wybitny językoznawca, inspektor szkolny. Był uczonym S. John's College w Cambridge. Po ukończeniu studiów w Londynie w 1887 r. objął stanowisko asystenta magistra w Rugby School, a następnie dyrektora Queen's College w Tauton w 1888 r. W latach 1896-1908 pełnił rolę inspektora szkolnego (Her Majesty's Inspector of Schools). Publikował w prasie artykuły z obszaru edukacji, literatury i polityki w j. angielskim oraz walijskim.

5 Sir Robert Laurie Morant (1863-1920) - angielski działacz oświatowy i administrator szkolny. Studiował teologię w Winchester College i w New College w Oksfordzie. Po roku przygotowań w Preparatory School (szkole dla nauczycieli) pełnił funkcję tutora księcia Syjamu. Był członkiem Board of Education, a następnie prywatnym sekretarzem sir Johna Gorst'a - wiceprzewodniczącego komisji szkolnej (Committee on Education). Był odpowiedzialny za niektóre rozwiązania wprowadzone w ustawie The Education Act z 1902 r. W 1903 r. został mianowany sekretarzem Rady ds. Edukacji (Education Board). W 1911 r. został skrytykowany przez Edmunda Holmesa za błędy inspektorów szkolnych, co zmusiło go do rezygnacji ze stanowiska.

${ }^{6}$ J. Miąso, op. cit., s. 86.

${ }^{7}$ A. Gromkowska-Melosik, op. cit., s. 71. 
do współczesnych analiz dokonanych przez brytyjskiego historyka edukacji Garry’ego McCullocha ${ }^{8}$ oraz słynną oryginalną publikację M. Arnolda pt. A French Eton, or middle-class education and the State („Francuski Eton lub edukacja klasy średniej i państwo", tt. A.W.). We French Eton... M. Arnold analizował specyfikę francuskiego szkolnictwa średniego, odwołując się do porównań z najsłynniejszą angielską szkołą średnią dla chłopców - Eton. Publikacja ta została ponownie wydana już w XX w. w monografii zredagowanej przez Petera Smitha i Geoffreya Summerfileda9.

Obecnie historyczne analizy porównawcze rozwoju systemów edukacyjnych czy też myśli pedagogicznej wymagają jeszcze szerszego spojrzenia. Jak podawał bowiem autorytet $\mathrm{w}$ światowej pedagogice porównawczej Harold J. Noah, zadaniem pedagogów porównawczych jest informowanie o poczynionych postępach w rozumieniu procesów, które złożyły się na rozwój edukacji oraz wyjaśnienie powiązań pomiędzy zmianami w systemach szkolnictwa i szerzej zmianami społecznymi ${ }^{10}$. A takie podejście thumaczy popularność analiz socjologicznych we współczesnej komparatystyce edukacyjnej.

Próba ukazania M. Arnolda jako pioniera angielskiej pedagogiki porównawczej na podstawie analiz historyczno-oświatowych oraz socjologicznych może stanowić pewne novum w polskiej pedagogice. Sięgając na nowo do oryginalnych publikacji M. Arnolda oraz współczesnych opracowań jego dorobku w wydaniu uznanych brytyjskich badaczy, można bowiem przy odwołaniu się do klasycznych teorii socjologicznych rzucić nowe spojrzenie na jego sposób myślenia o szkolnictwie i wychowaniu. Należy podkreślić, iż angielskie szkolnictwo ${ }^{11}$ pod wieloma względami różni się od systemów szkolnych w innych krajach europejskich. Jest ono pochodną odmiennej tradycji i historii oraz wynikających z nich różnic religijnych, odmiennego tempa rozwoju społeczeństwa i zmiany społecznej, której przejawem było osiągnięcie powszechnego dostępu do edukacji. Brak państwowego systemu szkolnego jeszcze w pierwszej połowie XIX w. tłumaczyć może dominacja ideologii konserwatyzmu w angielskim społeczeństwie. Dopiero wzrost popularności liberalizmu stał się jednym z czynników, wpływających na proces tworzenia szkolnictwa powszechnego, za które odpowiedzialne było państwo.

Poglądy M. Arnolda na edukację były przedmiotem szerszych analiz przede wszystkim w licznych publikacjach naukowych brytyjskich oraz amerykańskich komparatystów i historyków wychowania. Spośród licznego grona należy wymienić m.in.:

${ }^{8}$ G. McCulloch, Education and the Middle Classes: The Case of the English Grammar Schools 18681944, „History of Education” 2006, vol. 35, no. 6, s. 687-704.

9 M. Arnold, A French Eton, or middle-class education and the State, w: Matthew Arnold and the Education of a New Order, red. P. Smith, G. Summerfield, Cambridge 1969.

${ }^{10}$ H.J. Noah, Fast-Fish and Loose-Fish in Comparative Education, „Comparative Education Review” 1976, vol. 18 , no. 3 , s. 343 .

${ }^{11}$ Mówiąc o systemie edukacji we współczesnej Wielkiej Brytanii, należy zaznaczyć, że zgodnie z tradycją mamy tu do czynienia ze zdecentralizowanym systemem edukacyjnym, oddzielnym dla historycznych części Zjednoczonego Królestwa: Anglii i Walii, Szkocji oraz Irlandii Północnej. W niniejszym opracowaniu wszelkie analizy dotyczą wyłącznie systemu szkolnego w Anglii. 
Garry'ego McCullucha, Davida Philipsa, Roberta Andersona, Brendana A. Rapple'a, Donalda D. Stone'a oraz Johna F. Kuhna Jr. ${ }^{12}$. Ważną publikacją było również The Educational Thought and Influence of Matthew Arnold autorstwa australijskiego badacza Williama F. Connella ${ }^{13}$. Nowatorstwo myślenia M. Arnolda o szkolnictwie angielskim i XIX-wiecznych reformach szkolnych w Europie jest jednak bardzo słabo znane w polskiej komparatystyce edukacyjnej.

Celem niniejszego artykułu jest ukazanie poglądów M. Arnolda na rozwój szkolnictwa w Europie Zachodniej, przy odwołaniu się do klasycznych teorii socjologicznych: konserwatyzmu i liberalizmu. W oryginalnych publikacjach M. Arnolda, w których dokonywał on analizy stanu szkolnictwa w poszczególnych krajach europejskich, szczególnie wyraźnie widać popieraną przez niego ideologię liberalizmu.

\section{Rozwój angielskiego szkolnictwa w XIX wieku i początki pedagogiki porównawczej}

Przemiany $\mathrm{w}$ angielskim szkolnictwie w XIX w. były nieodzownie związane ze zmianami społecznymi, które się wówczas dokonywały. W angielskim społeczeństwie zmniejszała się stopniowo rola konserwatyzmu, a coraz większą popularność zyskiwał liberalizm. Ponadto ważnym czynnikiem wpływającym na kreowanie polityki edukacyjnej angielskiego rządu był rozwój komparatystyki edukacyjnej, którą jako pierwsi zajmowali się na Wyspach Brytyjskich urzędnicy państwowi - tzw. inspektorzy szkolni.

Za ojca pedagogiki porównawczej niemal powszechnie uznaje się Marca-Antoine'a Julliena de Paris (1775-1848), a jego dzieło pt. Esquisse et vues préliminaires d'un ouvrage sur l'education compare, które wydawane było w latach 1816-1817, przyjęło się za źródło wiedzy o tym nowym obszarze badań naukowych. Jednak wybitny współczesny amerykański komparatysta Erwin H. Epstein podaje w wątpliwość przypisywanie Jullienowi de Paris pierwszeństwa w tworzeniu podstaw pedagogiki porównawczej ${ }^{14}$. Inny amerykański komparatysta Harold J. Noah za mistrzów pedagogiki porównawczej

${ }^{12}$ Zob. G. McCulloch, op. cit., s. 687-704; G. McCulloch, Cyril Norwood and the English Tradition of Education, „Oxford Review of Education” 2006, vol. 32, no. 1, s. 55-69; D. Phillips, Beyond Traveller's Tales: Some Nineteenth-century British Commentators on Education in Germany, „Oxford Review of Education” 2000, vol. 26, no. 1, s. 49-62; R. Anderson, The Idea of the Secondary School in Nineteenth-century Europe, „Paedagogica Historica”, vol. 40, no. 1-2, s. 93-106; B.A. Rapple, Matthew Arnold and English Education. The Poet's Pioneering Advocacy in Middle Class Instruction, McFarland\& Company Inc., Publishers, Jefferson, North Carolina 2017; D.D. Stone, Communications with the Future: Matthew Arnold in Dialogue: Henry James, Charles-Augustin Sainte-Beuve, Ernest Renan, Michel Foucault, Friedrich Nietzsche, Hans-George Gadamer, William James, Richard Rorty, John Dewey, University of Michigan Press, Michigan 1997; J.F. Kuhn Jr., Some Notes on Matthew Arnold's Though on Education and Culture, „Notre Dame English Journal” 1971, vol. 7, no. 1, s. 52-66.

13 W.F. Connell, The Educational Thought and Influence of Matthew Arnold, Routledge, Londyn 1950.

${ }^{14}$ Zob. E.H. Epstein, Is Marc-Antoine Jullien de Paris the 'Father' of Comparative Education?, „Compare: A Journal of Comparative and International Education” 2017, no. 47, vol. 3, s. 317-331. 
uznawał M.-A. Julliena de Paris, M. Arnolda, Michaela E. Sadlera, Issaca L. Kandela, Nicolasa Hansa i Pedra Rossellò, wymieniając te nazwiska w jednym rzędzie. Według niego pedagogika porównawcza wyrosła z intensywnej ciekawości dotyczącej działania innych narodowych systemów edukacyjnych ${ }^{15}$. A właśnie takie działania realizował w pracy na stanowisku inspektora szkolnego M. Arnold.

Rozwój angielskiego szkolnictwa przebiegał zdecydowanie odmiennie niż w innych krajach europejskich. Za główny powód takiego stanu rzeczy Peter Sandiford w znanej publikacji Szkolnictwo angielskie z początków XX w. uznawał „wrodzony konserwatyzm” angielskiego społeczeństwa, określając go wybitnym rysem angielskiej administracji szkolnej. Konserwatyzm w edukacji przejawiał się w angielskim społeczeństwie jako troska o zachowanie tych rozwiązań, które były najlepsze i z których słynęły angielskie szkoły. Większość ustaw szkolnych uchwalanych przez parlament w XIX w. była bardzo konserwatywna. Dopiero od początków XX w. angielskie szkolnictwo zaczęło się zmieniać, a konserwatyzm w myśleniu o edukacji stał się mniej widoczny ${ }^{16}$. Przekształcenia te następowały jednak bardzo powoli, do głosu musieli dojść przedstawiciele innych warstw społecznych i innych wyznań. Rezultatem wprowadzanych stopniowo reform miało być zapewnienie powszechnego dostępu do edukacji dla wszystkich dzieci, bez względu na płeć, pochodzenie społeczne czy wyznanie.

Od czasów rewolucji przemysłowej w XVIII w. rozwijała się angielska klasa średnia, która zaczęła osłabiać uprzywilejowaną pozycję arystokracji. Z kolei rosnąca w siłę klasa robotnicza coraz odważniej zaczynała walczyć o swoje prawa, m.in. prawo do nauki. Angielskie szkolnictwo w odróżnieniu od systemu edukacji w innych krajach europejskich rozwijało się bardzo długo poza jakąkolwiek kontrolą państwa, a rząd nie miał prawa narzucać swoim obywatelom ani sposobu organizacji szkoły, programu nauczania, ani metod pracy ${ }^{17}$. Na początku XIX w. szkoły elementarne były prowadzone albo przez osoby prywatne, albo związki wyznaniowe, szczególnie przez organizacje pozaanglikańskich, niezależnych Kościołów - British and Foreign Schools Society (BFSS), oraz przez National Society, które z kolei zostało założone prze Kościół anglikański ${ }^{18}$. Obie te instytucje bardzo długo wyręczały władze państwowe w zajmowaniu się szkolnictwem.

Do końca pierwszej połowy XIX w. szkolnictwo angielskie odzwierciedlało klasowy podział społeczeństwa. Dzieci z niższych warstw społecznych uczyły się na bardzo niskim poziomie. Jedynie chłopcy z rodzin arystokratycznych oraz zamożnej klasy średniej mogli się uczyć w słynnych Public Schools ${ }^{19}$. Duży problem stanowiła również

15 H.J. Noah, op. cit., s. 344.

16 P. Sandiford, Szkolnictwo angielskie, tłum. W. Gumplowicz, Warszawa 1927, s. 12-13.

17 J. Miąso, op. cit., s. 91-92.

18 J.E. Dunford, Her Majesty's Inspectorate of Schools since 1944. Standard Bearers of Turbulent Priests?, Routledge, Londyn-Nowy Jork 1998, s. 1.

19 Termin Public Schools wbrew nazwie oznacza najbardziej prestiżowe formy szkół dla chłopców. Szkoły te cechowała całkowita niezależność od państwa i lokalnej społeczności. Najczęściej były to placówki 
edukacja dziewcząt, które zazwyczaj objęte były jedynie nauczaniem domowym i to na różnym poziomie. Szkoły dla dzieci z ubogich warstw społecznych spoczywały głównie w rękach Kościoła anglikańskiego. Brakowało w nich przede wszystkim jednolitego programu nauczania i podręczników. Problemem było również słabe przygotowanie nauczycieli. W XIX w. Kościół anglikański stał na stanowisku, że edukacja powinna być dostępna dla wszystkich dzieci ze wszystkich warstw społecznych, ale poglądu tego nie podzielali wszyscy anglikanie. Wpływowi podatnicy oraz właściciele fabryk zatrudniający dzieci odnosili się do tych pomysłów mniej entuzjastycznie. Powołane w $1811 \mathrm{r}$. National Society for Promoting the Education of the Poor in the Principles of the Established Church było organizacją, której cel polegał na tworzeniu szkół w każdej parafii. Program nauczania obejmujący tzw. ,trzy R” (reading, writing, arithmetics), czyli czytanie, pisanie, arytmetykę, uzupełniono o czwarte „R” - religię (religion). Przedstawiciele pozostałych Kościołów, liberalni anglikanie oraz część katolików i żydów opowiadali się za mniej wyznaniowym podejściem do edukacji. Utworzone w 1814 r. British and Foreign School Society miało na celu sprawowanie kontroli nad działalnością sieci szkół wyznaniowych, w których uczono Pisma Świętego oraz ogólnych zasad chrześcijaństwa, ale w formie bezwyznaniowej ${ }^{20}$. W sprawach politycznych przedstawiciele tej organizacji zajmowali zdecydowanie stanowisko liberalne, byli jednak w mniejszości i dopiero rozpoczynali walkę o uzyskanie wpływów w rządzie.

W kwestii edukacji przedstawiciele Kościoła anglikańskiego stali zdecydowanie po stronie konserwatyzmu, a jedynie część anglikanów oraz będący w mniejszości katolicy i żydzi upatrywali w liberalizmie szansy na zrównanie swoich praw. Konserwatyzm był w ówczesnej Anglii dominującą ideologią, rozumianą nie tylko jako przeciwstawianie się wszelkim zmianom społecznym, ale także dbanie o to, aby zmiany, pojmowane jako konieczność dziejowa, nie naruszały podstaw ładu społecznego ${ }^{21}$. Należy pamiętać, że Anglia jest też ojczyzną liberalizmu, który stał się ideologią modernizacji społeczeństw zachodnich i zakładał m.in. prawa jednostki oraz likwidację przywilejów, również w sektorze szkolnictwa. Jednym z najsłynniejszych twórców liberalizmu był John Stuart Mill $^{22}$. To właśnie ideologia liberalizmu znacząco przyczyniała się do upowszechnienia w Anglii edukacji na poziomie szkół elementarnych, ale miała także wpływ na zreformowanie istniejących szkół średnich i rozwój szkół średnich dla dziewcząt. Przedstawiciele mniejszości wyznaniowych, opowiadając się za liberalizmem, mieli szanse na zrównanie swoich praw także w zakresie dostępu do szkół i prowadzenia własnych pla-

\footnotetext{
z internatem, dostępne jedynie dla bogatych rodzin, które mogły wnosić za naukę dziecka bardzo wysokie opłaty. Do najsłynniejszych Public Schools zalicza się m.in. Eton, Westminster, Harrow, Rugby, Winchester, Charterhouse i St. Paul's.

${ }^{20}$ D. Gillard, Education in England: A Brief History 2011, http://www.educationengland.org.uk/history/ chapter05.html [dostęp: 22.01.2020].

${ }^{21}$ J. Szacki, Historia myśli socjologicznej, PWN, Warszawa 2002, s. 137-138.

22 Ibidem, s. 145-146.
} 
cówek oświatowych. Szczególnie katolicy zdawali sobie sprawę, że tylko dzięki równemu dostępowi do szkół będą mieli szanse na budowanie własnych elit intelektualnych i odzyskanie wpływów w rządzie. Jednak jeszcze na początku XIX w. uniwersytety w Oksfordzie i Cambridge były zamknięte dla wszystkich oprócz anglikanów. Po fali prześladowań katolików, która od czasów reformacji miała miejsce w Anglii dopiero w drugiej połowie XIX w. odzyskali oni prawo do prowadzenia własnych szkół. Najważniejszym wydarzeniem było jednak przyjęcie w $1871 \mathrm{r}$. przez parlament tzw. Universities Test Act, ustawy na mocy której przedstawiciele innych grup religijnych uzyskali prawo do podejmowania studiów na uniwersytetach Oksford, Cambridge oraz Durham, na wszystkich wydziałach oraz we wszystkich college'ach uniwersyteckich ${ }^{23}$. Było to niezwykle ważne wydarzenie w historii angielskiego szkolnictwa - otwarcie się dwóch najstarszych uniwersytetów na przedstawicieli innych wyznań poza anglikańskim dawało bowiem ogromne szanse na tworzenie elit intelektualnych w innych grupach społecznych i odbierało anglikanom monopol na władzę w państwie.

W pierwszej połowie XIX w. władza państwowa była obojętna na szkolnictwo elementarne, które stanowiło wyłącznie domenę filantropii kościelnej i świeckiej. Dużą rolę w organizacji szkolnictwa elementarnego odegrały szkoły niedzielne (Sunday Schools), a ich szybki rozwój przyczynił się do podjęcia działań nad organizacją nauczania powszechnego ${ }^{24}$. W $1833 \mathrm{r}$. w angielskim parlamencie po raz pierwszy poruszono kwestię powszechnego nauczania dla całego społeczeństwa, ale partie polityczne uznały to hasło za przedwczesne. Zaczęto jednak przyznawać dotacje oraz subwencje dla instytucji filantropijnych, które zajmowały się prowadzeniem szkó ${ }^{25}$. Władza państwowa zaczęła stopniowo przejmować pieczę nad szkolnictwem od 1833 r., kiedy Izby Gmin zdecydowała o przekazaniu 20 tysięcy funtów na budowę szkół dla dzieci z ubogich rodzin. W kolejnych latach nakłady finansowe na szkolnictwo elementarne stale się zwiększały. W 1839 r. utworzono w ramach Rady Królewskiej komisję szkolną (Committee of Council on Education). Sekretarzem został mianowany James Kay-Shuttleworth, w 1847 r. wprowadził nowy system przygotowania nauczycieli (pupil-teacher system) ${ }^{26}$, w którym to zdolniejsi starsi uczniowie przechodzili praktyczne przygotowanie do przyszłej profesji nauczycielskiej. J. Kay-Shuttleworth wspierał szczególnie te szkoły, które wykazywały się najlepszą jakością nauczania, co przekładało się na uzyskanie większej dotacji finansowej ze strony rządu. W Committee of Council powołano specjalną instytucję inspektorów szkolnych - Her Majesty’s Inspectors (HMI), których zadaniem było

${ }^{23}$ Universities Test Act 1871, The National Archives, http://www.legislation.gov.uk/ukpga/Vict/34-35/26 [dostęp: 23.02.2020].

${ }^{24}$ J. Loria, Szkolnictwo w Anglii i jego tradycje, Zakład Narodowy im. Ossolińskich, Wrocław-WarszawaKraków 1964, s. 20-21.

25 Ibidem, s. 22.

${ }^{26}$ Zob. A. Włoch, The Development of Teachers Education in England in the $19^{\text {th }}$ Century, ,Przegląd Historyczno-Oświatowy" 2019, nr 1-2, s. 60-75. 
wizytowanie subwencjonowanych szkół i opracowywanie raportów oraz formułowanie opinii na temat polityki edukacyjnej27.

Wraz z aktywniejszą działalnością inspektorów szkolnych zaczęła się rozwijać w Anglii komparatystyka edukacyjna. Inspektorzy szkolni mieli za zadanie opracowywanie raportów na temat funkcjonowania angielskich szkół, które otrzymywały subwencje od rządu. W kolejnych latach za sprawą M. Arnolda, a później i jego następców, T. Darlingtona i R. Moranta, inspektorzy szkolni rozszerzyli swoją działalność także o raportowanie o stanie oświaty w innych krajach europejskich oraz wskazywanie kierunków rozwoju szkolnictwa w Anglii i kreowanie polityki edukacyjnej rządu. Stanowisko inspektora szkolnego cieszyło się wielkim szacunkiem wśród angielskiego społeczeństwa. Ogromną rolę odegrał tu M. Arnold, który jako wybitny poeta, krytyk literacki i profesor uniwersytecki do końca swojego życia pełnił również funkcję inspektora szkolnego. Inspektorzy szkolni mieli za zadanie wyszukiwanie możliwie najlepszych sposobów nauczania, wspieranie eksperymentalnego kształcenia, a przez to wskazywanie możliwych kierunków rozwoju edukacji, przygotowywanie projektów reform, jak również krytycznych ocen działalności istniejących szkół ${ }^{28}$. Raporty inspektorów szkolnych, począwszy od działalności M. Arnolda, nie były jedynie schematycznym opisem danego sektora edukacji. Autorzy tych raportów wykraczali bowiem w swoich analizach poza własne środowisko i kulturę. Niezwykle cenne w historycznym rozwoju pedagogiki porównawczej są zwłaszcza analizy funkcjonowania szkolnictwa w innych krajach europejskich, które publikowano po wizytacjach zagranicznych szkół. Raporty te cechują pogłębione obserwacje zmiany społecznej, która dokonywała się w ówczesnych europejskich społeczeństwach, ale także krytyczna ocena stanu angielskiego szkolnictwa, wyraźne wskazanie, które rozwiązania edukacyjne można z powodzeniem zaadaptować w angielskich szkołach różnych szczebli. Początki angielskiej komparatystyki edukacyjnej daleko wykraczały więc poza ówczesny stan badań w tym obszarze w innych częściach Europy.

Jedna za najważniejszych reform, które otworzyły drogę do utworzenia w Anglii państwowego systemu edukacji, to ustawa przygotowana przez liberała Williama E. Fostera - Elementary Education Act z 1870 r., zwana niekiedy Foster 's Act. Ustawa ta była formą kompromisu pomiędzy liberałami a przedstawicielami Kościoła anglikańskiego. Nie naruszała dualizmu angielskiego szkolnictwa, nie wprowadziła ani obowiązkowości, ani bezpłatności nauczania, ale w znacznym stopniu ograniczała wpływy Kościoła anglikańskiego ${ }^{29}$. Wraz z przyjęciem tej ustawy rząd zaakceptował finalnie odpowiedzialność za organizację szkolnictwa dla wszystkich dzieci. Ustawa Fostera rozpoczęła proces upowszechniania szkolnictwa państwowego, który to zajął Anglikom ponad dwadzieścia lat. Ustanowiono w tym czasie rady szkolne. Ich zadanie miało polegać

\footnotetext{
${ }^{27}$ J. Miąso, op. cit., s. 96-97; D. Gillard, op. cit.

28 P. Sandiford, op. cit., s. 17.

29 J. Miąso, op. cit., s. 102-103; J. Loria, op. cit., s. 25.
} 
na nadzorowanie i uzupełnieniu sieci szkół. Takie rozwiązanie było akceptowalne dla wielu grupowych interesów religijnych ${ }^{30}$.

W 1880 r. przyjęto ustawę o wychowaniu, która wprowadzała obowiązek szkolny dla wszystkich dzieci w wieku od 5 do 10 lat $^{31}$. Nie od razu udało się jednak zrealizować jej założenia. Niemniej jednak w 1880 r. szkoła elementarna w Anglii stała się obowiązkowa. Publiczna, a z czasem i całkowicie bezpłatna szkoła elementarna była jedyną instytucją zapewniającą powszechną edukację dzieci z niższych warstw społecznych, a przede wszystkim z klasy robotniczej. W 1899 r. utworzono w Anglii Board of Education, instytucję, która de facto pełniła rolę ministerstwa edukacji. Dopiero więc pod koniec XIX w. Anglia miała zorganizowany państwowy system edukacji elementarnej, ale poziom nauczania w tych szkołach był nadal bardzo niski ${ }^{32}$.

Niezwykle ważnym wydarzeniem w procesie tworzenia narodowego systemu angielskiej edukacji było uchwalenie w 1902 r. ustawy tzw. Balfour Act, od nazwiska ówczesnego premiera Arthura J. Balfoura. Właściwym autorem tego dokumentu był jednak inspektor szkolny - R. Morant, wybitny przedstawiciel administracji państwowej oraz uznany komparatysta. Ustawa ta znosiła rady szkolne oraz nakładała odpowiedzialność za szkoły na rady hrabstw i miast, które zostały wydzielone jako lokalne władze oświatowe (LEA - Local Education Authorities) ${ }^{33}$.

W XIX w. angielskie szkolnictwo średnie to przede wszystkim grammar schools, które w opinii publicznej postrzegane były jako najlepszy wzór nauczania w szkołach drugiego stopnia, oraz elitarne English Public Schools. W pierwszej połowie XIX w. angielskie grammar schools nie miały jednolitego programu kształcenia, szkoły te różniły się także pod względem organizacyjnym, wiele $\mathrm{z}$ nich było bowiem szkołami internatowymi. Elitarne szkoły z internatem, utrzymywane przez rozmaite zapisy fundacyjne, przeznaczone były wyłącznie dla najbogatszych warstw społecznych - angielskiej arystokracji. Sytuacja zaczęła się zmieniać, gdy rosnąca w siłę angielska klasa średnia, domagająca się dostępu do elitarnych szkół średnich oraz wyższych, rozpoczęła krytykę działalności grammar schools, podkreślając, że szkoły te skupiają się przede wszystkim na nauczaniu języków klasycznych, ignorując znaczenie nauk ścisłych i przyrodniczych. Znaczącą rolę w reformie angielskich szkół średnich odegrał Thomas Arnold, który zreformował Rugby School, czyniąc z tej szkoły jedną z najlepszych elitarnych szkół średnich i wyznaczając kierunek reform dla innych Public Schools ${ }^{34}$.

Szkoły średnie w Anglii zaczęły się reformować w połowie XIX w. Taunton Commission, która miała za zadanie zbadanie stanu nauczania w grammar schools, wykazała

${ }^{30}$ D. Gillard, op. cit., http://www.educationengland.org.uk/history/chapter06.html [dostęp: 23.02.2020].

31 W.H.G. Armytage, A.J. Mundella as Vice-President of the Council, and the Schools Question, 18801885, „The English Historical Review” 1948, vol. 63, no. 246, s. 52-82.

32 J. Loria, op. cit., s. 26; J. Miąso, op. cit., s. 103-104.

33 J. Miąso, op. cit., s. 104.

${ }^{34}$ G. McCulloch, Cyril Norwood, op. cit., s. 59; J. Miąso, op. cit., s. 118. 
w 1869 r., że wiele z nich kładło już duży nacisk na nauki przyrodnicze i ścisłe, co było wówczas ogólnoeuropejskim trendem. Poczynione przez M. Arnolda obserwacje oraz analizy szkolnictwa średniego w innych krajach europejskich wykazały, że angielskie grammar schools powinny naśladować w kwestii programu nauczania pruskie gimnazja. Aby zachować oryginalność angielskich szkół, Taunton Commission zalecała jednak utrzymanie łaciny i greki oraz kultury klasycznej w programach nauczania, dodając jednak kilka przedmiotów przyrodniczych. W tym samym czasie ewolucję przeszły także elitarne English Public Schools ${ }^{35}$. Obok niezwykle ważnego wykształcenia klasycznego, szkoły te zaczęły kłaść większy nacisk na wychowanie fizyczne, biorąc przykład z Rugby School. English Public Schools specjalizowały się także w przygotowaniu przyszłej kadry administracji państwowej oraz wojskowej. Wychowankowie English Public Schools byli znakomitymi politykami, wojskowymi, duchownymi, ale także i znanymi działaczami społecznymi.

W XIX w. angielskie uniwersytety nie były instytucjami państwowymi. W odróżnieniu od uniwersytetów niemieckich czy francuskich pieczę nad nimi trzymał Kościół, w tym przypadku anglikański. Przedstawiciele innych religii nie mieli dostępu do najstarszych uniwersytetów - Oksfordu i Cambridge - aż do uchwalenia wspomnianego już Universities Test Act w 1871 r. W początkach XIX w. angielskie uniwersytety postrzegano jako zacofane, prawie nie prowadzono w nich badań naukowych, a poziom nauczania był bardzo niski, ignorowano rolę nauk przyrodniczych i ścisłych. Dopiero powstanie nowych uczelni, w 1828 r. University College i King's College w 1829 r. (połączonych w 1836 r. w jedną uczelnię - University of London), a także w 1832 r. Durham University, wymusiło niejako konieczność zreformowania najstarszych uni-

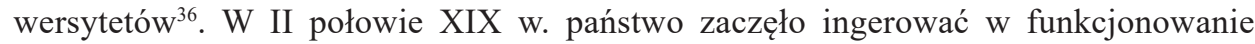
uniwersytetów, wydając w $1854^{37}$ i $1856^{38}$ r. ustawy parlamentarne, które nakazywały m.in. prowadzenie wykładów w języku angielskim oraz poszerzenie programu studiów o nauki ścisłe. Niezwykle istotne znacznie w reformowaniu angielskich uniwersytetów miała działalność tzw. ruchu oksfordzkiego, zapoczątkowanego w latach 30. XIX wieku, w którym szczególną rolę odegrali późniejszy kardynał John Henry Newman ${ }^{39}$ oraz

35 J. Miąso, op. cit., s. 122-124.

${ }^{36}$ Ibidem, s. 135, 138.

37 Oxford University Act 1854, legislation.gov.uk, https://www.legislation.gov.uk/ukpga/Vict/17-18/81/contents [dostęp: 16.10.2020].

${ }_{38}$ Cambridge University Act 1856, legislation.gov.uk, https://www.legislation.gov.uk/ukpga/Vict/19-20/88/ crossheading/constitution-of-the-university [dostęp: 16.10.2020].

39 John Henry Newman (1801-1890) - filozof, teolog, duchowny anglikański. Po dokonaniu konwersji na katolicyzm w 1845 r., został kardynałem Kościoła katolickiego w 1879 r. Był założycielem ruchu oksfordzkiego, skupiającego wpływowych przedstawicieli Kościoła anglikańskiego w Oksfordzie. Celem działalności ruchu było m.in. zreformowanie szkolnictwa i zapewnienie równego dostępu do szkół dla katolików. J.H. Newman przyczynił się do założenia katolickiego uniwersytetu w Dublinie, działał na rzecz podniesienia poziomu edukacji mniejszości katolickiej w Anglii. Został ogłoszony świętym Kościoła katolickiego. 
Thomas Arnold. J.H. Newman podkreślał, że zadaniem uniwersytetu jest nie tylko zapewnienie wykształcenia ogólnego, ale także wychowanie gentlemana, opierając się na kulturze klasycznej, mniejszą wagę przywiązując do badań naukowych ${ }^{40}$. W drugiej połowie XIX w. J.H. Newman, wyraźnie sympatyzujący z katolicyzmem, stał się także orędownikiem walki o dostęp do szkół dla katolików i przedstawicieli wyznań spoza Kościoła anglikańskiego, wspierając tym samym dążenie angielskiego społeczeństwa do zapewnienia wszystkim obywatelom powszechnej edukacji ${ }^{11}$.

Anglicy, szczególnie ci należący do wyższych warstw społecznych, bardzo interesowali się przemianami w szkolnictwie w kontynentalnej Europie, zwłaszcza we Francji, Prusach, Holandii i Szwajcarii, ale do wprowadzonych tam rozwiązań podchodzili z właściwym sobie dystansem. Najsłynniejsze reformy edukacji oraz nowe koncepcje kształcenia stawały się przedmiotem analiz i różnego rodzaju rozpraw działaczy społecznych oraz publicystów. Działalność inspektorów szkolnych w II połowie XIX w. przyczyniła się znacząco do rozwoju nowej dziedziny, którą jest współcześnie pojmowana pedagogika porównawcza. Na uwagę zasługuje również to, że raporty najsłynniejszych inspektorów szkolnych, z M. Arnoldem na czele, nie były jedynie pozbawionym oceny i diagnozy opisem zastanego stanu szkolnictwa, ale także wyrażały opinie inspektorów o możliwościach rozwoju angielskich szkół w poszczególnych sektorach. Ponadto podróże inspektorów do innych krajów europejskich, odwiedzanie tamtejszych szkół oraz publikowane przez nich raporty dawały asumpt władzy państwowej do wprowadzenia w Anglii nowoczesnych rozwiązań edukacyjnych, które sprawdziły się w innych państwach.

\section{Matthew Arnold (1822-1888) - życie i twórczość}

Matthew Arnold był jednym z najsłynniejszych wiktoriańskich pisarzy, poetą, filozofem kultury, krytykiem literackim i społecznym, profesorem na Uniwersytecie w Oksfordzie, a jednocześnie najbardziej znanym inspektorem szkolnym. Dzięki tej ostatniej funkcji, którą z pełnym zaangażowaniem pełnił M. Arnold, w literaturze anglosaskiej przyjmuje się go nazywać pionierem pedagogiki porównawczej w Anglii oraz pierwszym badaczem polityki edukacyjnej ${ }^{42}$.

M. Arnold urodził się 24 grudnia w 1822 r. w Laleham-on-Thames w hrabstwie Middlesex w Anglii, jako najstarszy syn dra T. Arnolda ${ }^{43}$ - słynnego reformatora

\footnotetext{
40 J. Miąso, op. cit., s. 134-140.

${ }^{41}$ M. Martín-Sánchez, J. Cáceres-Muñoz, Cardinal Newman: His Importance for Catholic Education, „International Studies in Catholic Education" 2016, vol. 8, no. 1, s. 29-43.

${ }^{42}$ F. Clarke, Introduction, w: W.F. Connell, op. cit, s. ix.

43 Thomas Arnold (1795-1842) - angielski pedagog, historyk, pastor anglikański. W latach 1828-1842 był dyrektorem Rugby School - jednej z najsłynniejszych angielskich elitarnych szkół średnich z internatem dla chłopców (tzw. English Public Schools). Szkoła ta była przeznaczona głównie dla synów arystokracji
} 
Rugby School, zaliczanej do elitarnych English Public Schools, oraz Mary Penrose Arnold, córki anglikańskiego pastora. M. Arnold uczył się w Winchester College, później w 1837 r. rozpoczął naukę w Rugby School, a następnie, uzyskawszy stypendium Balliol College, zaczął studia na Uniwersytecie w Oksfordzie, gdzie studiował literaturę klasyczną ${ }^{44}$. Wykształcenie, które odebrał M. Arnold, jest niezwykle istotne w całej jego karierze, nie tylko literackiej czy uniwersyteckiej, ale przede wszystkim jako najznakomitszego inspektora szkolnego. Ukończenie prestiżowej Rugby School dało mu doskonałe przygotowanie do podjęcia studiów uniwersyteckich. Dodatkowo jego liberalny światopogląd został w dużej mierze ukształtowany przez ojca. M. Arnold odebrał doskonałą edukację, bez wątpienia dającą wstęp do angielskich elit intelektualnych.

W 1843 r. M. Arnold otrzymał prestiżową nagrodę dla najlepszego studenta Oksfordu w dziedzinie poezji - the Newdigate Prize za swój wiersz pt. Cromwell. Studia ukończył z wyróżnieniem na drugim miejscu w $1844 \mathrm{r}^{45}$. W kolejnym roku został wybrany członkiem społeczności Oriel College (pierwszego królewskiego kolegium oksfordzkiego), którego członkami byli także jego ojciec i J.H. Newman ${ }^{46}$. Co niezwykle interesujące, M. Arnold łączył renomę Uniwersytetu w Oksfordzie z osobą J.H. Newmana i założonym przez niego ruchem oksfordzkim. Dla M. Arnolda, który był liberalnym anglikaninem, jak jego ojciec, Uniwersytet w Oksfordzie i J.H. Newman (mimo jego późniejszej konwersji na katolicyzm) zawsze pozostawały wspólnym symbolem duchowego piękna i kultury ${ }^{47}$.

M. Arnold publikował utwory literackie, szczególnie poezję. W 1847 r. został prywatnym sekretarzem lorda Lansdowne, który kierował Committee of Council on Education (komisji szkolnej). W 1851 r., chcąc zarobić pieniądze potrzebne na zabezpieczenie finansowe swojego małżeństwa z Frances Lucy Wightman, przyjął posadę inspektora szkolnego (Her Majesty's Inspector of Schools). Funkcję tę pełnił nieprzerwanie przez

\footnotetext{
i zamożnej klasy średniej. Zreformowana przez Thomasa Arnolda Rugby School bardzo szybko znalazła się na czele rankingów szkół średnich i stała się wzorem dla innych elitarnych Public Schools. Reforma szkoły obejmowała wprowadzenie innowacyjnych metod nauczania (system monitorialny), zmiany w programie nauczania, zwiększenie nacisku na matematykę i nauki przyrodnicze, wprowadzenie nauczania języków obcych nowożytnych (j. francuskiego i j. niemieckiego), kosztem realizacji klasycznego programu kształcenia. Niezwykle ważnym elementem nowego programu w Rugby School było wychowanie fizyczne i kładzenie nacisku na gry zespołowe, przy jednoczesnym akcencie na wychowanie religijne i moralne (tzw. Muscular Christianity - typowe dla Rugby School). T. Arnold wprowadził nowy sposób zarządzania szkołą, z większymi kompetencjami dyrektora. Ograniczył stosowanie kar fizycznych. Celem reformy Rugby School było stworzenie szkoły dla gentelmenów. T. Arnold był autorem History of Rome oraz Introductory Lectures on Modern History.

${ }^{44}$ B.A. Rapple, op. cit., s. 9.

${ }^{45}$ W.F. Connell, op. cit, s. vii; K. Campbell, Matthew Arnold, Oxford University Press, Oxford 2008, s. 14 .

${ }^{46}$ B.A. Rapple, op. cit., s. 9.

${ }^{47}$ B. Willey, Matthew Arnold, w: Encyclopaedia Britannica, https://www.britannica.com/biography/Matthew-Arnold, [dostęp 18.02.2020].
} 
trzydzieści pięć lat, podnosząc rangę tej instytucji oraz stając się najsłynniejszym inspektorem szkolnym. Jednocześnie w latach 1857-1867 był profesorem poezji na Uniwersytecie w Oksfordzie. Przez ponad trzy dekady (1851-1883) M. Arnold z powodzeniem łączył pracę profesora $\mathrm{i}$ literata $\mathrm{z}$ bardzo odpowiedzialnym stanowiskiem inspektora szkolnego. W $1870 \mathrm{r}$. awansował na stanowisko senior inspector, a w $1884 \mathrm{r}$. został szefem inspektorów szkolnych ${ }^{48}$. Swoje analizy szkolnictwa w Europie publikował po to, aby skupić uwagę angielskiego rządu na tym, co udało się osiągnąć w organizacji szkolnictwa, głównie we Francji i w Prusach. Jego słynne raporty o angielskich szkołach elementarnych, obejmujące wszystkie reformy wprowadzane w latach 1852 1882, stały się niezwykle przydatne dla angielskiego rządu i działaczy oświatowych, wkrótce po jego śmierci zostały opublikowane w szerokim nakładzie, a później jeszcze wznawiane. Raporty te charakteryzuje oryginalny styl i przejrzystość myśli autora ${ }^{49}$. Pełniąc funkcję inspektora szkolnego, M. Arnold odbył liczne podróże na brytyjskie prowincje, gdzie badał stan angielskich i walijskich szkół elementarnych. Kilkakrotnie rząd wysyłał go do Francji, Prus, Holandii, Włoch i Szwajcarii w celu zbadania tam stanu oświaty. Dwa z raportów M. Arnolda opisujące szkoły za granicą przedrukowane zostały jako książki. Największym uznaniem i zainteresowaniem cieszyły się: A French Eton, or a Middle-Class Education and the State ${ }^{50}$ oraz Schools and Universities on the Continent $^{51}$. W 1883 i 1886 r. M. Arnold dawał również gościnne wykłady w Stanach Zjednoczonych ${ }^{52}$.

M. Arnold jest znany przede wszystkim jako wybitny XIX-wieczny poeta oraz krytyk literacki i społeczny. Mówi się, że „kiedy poeta Arnold umarł, narodziła się krytyka" ${ }^{53}$. Do jego najsłynniejszych dzieł zalicza się Essays in Criticism ${ }^{54}$ oraz Culture and Anarchy ${ }^{55}$. M. Arnold zmarł nagle w Liverpoolu w 1888 r. $^{56}$. Pozostawił swoim następcom jasno wyznaczone kierunki działań w zakresie komparatystyki edukacyjnej oraz przeświadczenie o potrzebie kreowania reform oświatowych w Anglii w duchu liberalizmu.

48 B.A. Rapple, op. cit., s. 13.

49 D. Phillips, op. cit., s. 56.

${ }_{50}$ M. Arnold, A French Eton, or a Middle-Class Education and the State, Macmillan and Co., LondynCambridge 1864 .

51 M. Arnold, Schools and Universities on the Continent, Macmillan and Co., Londyn 1868.

52 D. Bush, Matthew Arnold: A Survey of His Poetry and Prose, Palgrave Macmillan, Londyn 1971, s. 16.

53 B. Willey, op. cit.

${ }_{54}$ M. Arnold, Essay in Criticism, Macmillan and Co., Londyn-Cambridge 1865.

${ }_{55}$ M. Arnold, Culture and Anarchy: an Essay in Political and Social Criticism, Smith, Elder and Co., Londyn 1869.

${ }^{56}$ K. Campbell, Matthew, op. cit., s. 13; P. Nash, Arnold, Matthew (1822-1888), w: Philosophy of Education. An Encyclopedia, red. J.J. Chambliss, Routledge, New York 1996, s. 36-37; D. Philips, op. cit., s. 56. 


\section{Poglądy Matthew Arnolda na europejskie szkolnictwo}

M. Arnold był nie tylko wybitnym angielskim poetą, ale przede wszystkim komparatystą, prekursorem w obszarze badań naukowych, które rozwinęły się pół wieku później. Jak podkreśla amerykański badacz B.A. Rapple, ważne jest, że M. Arnold nie był jedynie „krytykiem fotelowym”, cenzura jego narodowego systemu szkolnictwa opierała się bardziej na teorii aniżeli na praktyce. M. Arnold był jednym z inspektorów szkolnych (HMI) podróżującym po całej Anglii i Walii oraz raportującym o szkołach elementarnych i uczęszczających do nich dzieciach. Zagraniczne podróże służbowe dawały mu oficjalne możliwości zbadania, jak funkcjonują szkoły w innych państwach, informowania o tym angielskiego rządu, ale przede wszystkim wskazywania, jakie zagraniczne rozwiązania edukacyjne Anglia mogłaby zaadaptować w celu poprawy własnej struktury szkolnictwa oraz instytucji odpowiedzialnych za edukację. Podróże zagraniczne M. Arnolda odegrały niezwykle istotną rolę w rozwoju jego porównawczych poglądów na edukację oraz inne kwestie społeczne ${ }^{57}$. Nowatorstwo badań komparatystycznych M. Arnolda polegało bowiem również na odwołaniu się do analiz, które współcześnie są właściwe dla socjologii edukacji (subdyscypliny pedagogicznej rozwijającej się dopiero od lat 90. XX w.). M. Arnold dostrzegał, że edukacja odgrywa kluczową rolę w kształtowaniu się nowoczesnego państwa oraz istotnie wpływa na funkcjonowanie poszczególnych klas społecznych.

Pełniąc obowiązki inspektora szkolnego, M. Arnold wizytował szkoły w kontynentalnej Europie w roku 1859 i 1865. Pierwsza podróż zagraniczna zaowocowała wydaną w 1861 r. publikacją The Popular Education of France ${ }^{58}$, w której znalazły się również fragmenty dotyczące szkolnictwa w Holandii i Szwajcarii. W 1864 r. M. Arnold powrócił do analiz porównawczych w słynnej publikacji A French Eton, or a Middle-Class Education and the State. W następnym roku odbył podróże do Francji, Prus oraz Włoch celem opracowania raportów na temat szkół wyższych oraz uniwersytetów. Efektem jego pracy była nowatorska publikacja Schools and Universities on the Continent (1868). Do analizy pruskich uniwersytetów powrócił w kolejnym opracowaniu Higher Schools and Universities in Germany z 1874 r. ${ }^{59}$. Pruskie uniwersytety oceniał bardzo wysoko. Egzamin maturalny (Abitur) spotkał się z pełnym uznaniem M. Arnolda, który uważał, że jest to najlepsza forma egzaminu po odebraniu edukacji w szkole o tak wysokiej pozycji ${ }^{60}$. M. Arnold dostrzegał wyraźny kontrast pomiędzy działalnością pruskich i angielskich uniwersytetów, którego dowodem była znacznie wyższa liczba studentów w Prusach aniżeli w Anglii oraz zdecydowanie

\footnotetext{
57 B.A. Rapple, op. cit., s. 1.

${ }_{58}$ M. Arnold, The Popular Education of France: With Notices of that of Holland and Switzerland, Longman, Green, Longman and Roberts, Londyn 1861.

59 M. Arnold, Higher Schools and Universities in Germany, Macmillan and Co., Londyn 1874.

${ }^{60}$ D. Phillips, op. cit., s. 57.
} 
odmienny charakter studiów. Edukację uniwersytecką w Anglii cechowała rutyna, jak oceniał M. Arnold, z wyraźnym brakiem naukowości. Porównanie XIX-wiecznych uniwersytetów w Anglii, Francji i Prusach najlepiej obrazuje komentarz M. Arnolda: „The French University has no liberty, and the English Universities have no science; the German Universities have both”61 („Francuskie uniwersytety nie mają wolności, a angielskie nauki; niemieckie uniwersytety mają obie [te rzeczy], tł. A.W). M. Arnold zrobił więcej dla komparatystyki edukacyjnej w połowie XIX stulecia aniżeli ktokolwiek inny, tworząc wyważony i naukowo wartościowy, porównawczy opis szkolnictwa funkcjonującego w Prusach ${ }^{62}$.

Analizy porównawcze M. Arnolda daleko wybiegały w przyszłość, co znakomicie obrazuje konstrukcja jego publikacji The Popular Education of France wydanej w $1861 \mathrm{r}$. Nie było jeszcze wówczas rozwiniętej metodologii badań porównawczych, co nie przeszkodziło M. Arnoldowi w przygotowaniu publikacji odpowiadającej wszelkim wytycznym dla monografii z obszaru komparatystyki edukacyjnej. Publikacja The Popular Education of France składa się z trzech części: pierwsza to aż 14 rozdziałów tematycznych, dotyczących organizacji szkolnictwa we Francji, w historycznym ujęciu oraz porównanie do angielskich szkół, druga obejmuje analizę systemu szkolnictwa w Szwajcarii, a trzecia - w Holandii. W kolejnych rozdziałach pierwszej części publikacji M. Arnold przedstawia system szkolnictwa we Francji, szczegółowo opisuje, jak zmieniała się organizacja edukacji oraz program kształcenia w konkretnych epokach: przed rewolucją, po rewolucji, w czasach I republiki, epoki napoleońskiej, II republiki, aż do czasów współczesnych autorowi ${ }^{63}$. Sam układ treści nasuwa jednoznacznie na myśl wizję uprawiania komparatystyki edukacyjnej przez M. Arnolda, która to zakładała ścisły związek analiz komparatystycznych z historią wychowania. A taką metodę badań porównawczych propagował nieco później wybitny brytyjski komparatysta M.E. Sadler, który podkreślał, jak ważny dla lepszego zrozumienia specyfiki narodowego systemu edukacji jest kontekst historyczny i kulturowy. W publikacji The Popular Education of France M. Arnold zaprezentowat także problem finansowania i materialnego wsparcia francuskiego szkolnictwa, a także zanalizował kondycję intelektualną i moralną szkolnictwa w rejonie Paryża oraz szkół we francuskich prowincjach ${ }^{64}$. Rozdziały XIII i XIV tej monografii stanowią właściwe porównanie francuskiego i angielskiego systemu edukacji, od ustawodawstwa aż po skutki reform edukacyjnych dla zwykłych obywateli ${ }^{65}$. Porównania francuskiego i angielskiego szkolnictwa M. Arnolda są bardzo wyważone, ale i krytyczne. Autor uniknął przy tym etnocentryzmu. Doskonale rozumiał kontekst kulturowy, którego odbicie dostrzegał w organizacji szkolnictwa. W tym właśnie zakresie analizy komparatystyczne M. Arnolda

\footnotetext{
${ }^{61}$ M. Arnold, Schools and Universities on the Continent, Macmillan and Co., Londyn 1868, s. 232.

${ }^{62}$ D. Philips, op. cit., s. 56.

${ }^{63}$ M. Arnold, The Popular Education, op. cit., s. 1-85.

${ }^{64}$ Ibidem, s. 80-144.

${ }^{65}$ Ibidem, s. $145-174$.
} 
dowodzą, że zbudował on solidne podstawy dla rozwoju angielskiej oraz europejskiej pedagogiki porównawczej.

M. Arnold był pod wrażeniem organizacji szwajcarskich szkół elementarnych, wskazywał, że to właśnie w Szwajcarii, bardziej niż w innych krajach na kontynencie europejskim, dzieci ze wszystkich klas społecznych objęte są taką samą edukacją elementarną (primary school). Wizytując szkoły w kantonie Zurych, w tym szczególnie szkoły dla dzieci z ubogich rodzin, M. Arnold wskazywał na istotne podobieństwa tego regionu z Anglią. Podkreślał, że jest to region wolny jak Anglia, uprzemysłowiony i protestancki jak Anglia. Natomiast różnice widać w kwestii organizacji szkolnictwa elementarnego. W kantonie Zurych szkoły elementarne są obowiązkowe dla wszystkich dzieci, a jakość kształcenia w tych szkołach jest bardzo wysoka ${ }^{66}$. Argumenty te miały przekonać angielskie społeczeństwo do podjęcia starań o zorganizowanie państwowej, powszechnej edukacji dla wszystkich, bez względu na pochodzenie społeczne.

W kwestii obowiązkowej edukacji, jak również edukacji wyznaniowej i świeckiej M. Arnold stał na stanowisku, że kontynentalne precedensy należy poznawać i studiować, głównie z uwagi na doświadczenia innych krajów w tym zakresie. Szczególnie należy analizować te aspekty edukacji, które angielskie społeczeństwo uznaje aktualnie za ważne i w których to rozważa wprowadzenie konkretnych reform. M. Arnold zwracał przy tym uwagę, że większość angielskich liberałów wydaje się przekonana o tym, że angielskie szkoły elementarne powinny być bezwyznaniowe, a nauczanie świeckie oraz że w publicznej szkole elementarnej nie może być inaczej. Podkreślał, że w kontynentalnej Europie, wszędzie oprócz Holandii, publiczna szkoła elementarna jest szkołą wyznaniową ${ }^{67}$. Wydaje się, że M. Arnold doskonale rozumiał, iż zorganizowanie powszechnej edukacji elementarnej w Anglii wymagało będzie zmiany postaw angielskiego społeczeństwa, przede wszystkich zwolenników liberalizmu, będących członkami Kościoła anglikańskiego. Konieczne zatem będzie osłabienie wpływów anglikanów, chcących za wszelką cenę utrzymać dominację w organizacji szkolnictwa.

W swoich raportach o stanie szkolnictwa M. Arnold wykazywał się znajomością historii wychowania w Europie. Umiejętnie charakteryzował historyczny rozwój szkolnictwa, podkreślając, że wszystkie kraje Europy Zachodniej miały kontakt z grecką i rzymską cywilizacją. Kontakt, dzięki któremu wydawane były książki, publikacje naukowe, rozwijały się szkoły oraz nauka. Uważał, że Francja korzystała z dorobku cywilizacji starożytnej bardziej niż inne kraje. Wyjątkiem w Europie Zachodniej były tylko Włochy. Wszystkie kraje Europy Zachodniej w epoce feudalnego i katolickiego średniowiecza miały swoje uniwersytety. Zdaniem M. Arnolda jednym z najlepszych europejskich średniowiecznych uniwersytetów był Uniwersytet w Paryżu. Pod skrzydłami Kościoła katolickiego prowadzone były college oraz przygotowywano do pracy nauczycieli. To średniowieczne college dały początek szkołom średnim. W pewnym

\footnotetext{
${ }^{66}$ M. Arnold, Schools and Universities, op. cit., s. v.

${ }^{67}$ Ibidem, s. xvi.
} 
sensie zachodnioeuropejskie kraje w epoce średniowiecza stanowiły jedną społeczność. Pierwszeństwo w tej społeczności zajmowała według M. Arnolda właśnie Francja ${ }^{68}$.

W 1859 r., działając z upoważnienia królewskich inspektorów, którzy badali stan edukacji elementarnej w Anglii, M. Arnold udał się do Francji celem poznania, jak działają francuskie szkoły elementarne. Z uwagi na to, że wyżsi funkcjonariusze szkolni we Francji sprawowali nadzór nie tylko nad szkołami elementarnymi, ale i średnimi, skorzystał on z możliwości poznania również specyfiki funkcjonowania znanych francuskich szkół średnich. Pomimo tego, że nie zlecono mu oficjalnie badania szkół średnich, niezwykle zainteresowany tym zagadnieniem opracował szczegółowy raport z wizyty w liceum w Tuluzie. Z uznaniem podkreślał, że każde główne miasto ma szkołę średnią (liceum), które jest instytucją założoną i finansowaną przez państwo, prowadzoną z pomocą departamentu i gminy. Wszystkie francuskie licea połączone są w jedną sieć szkolną, podlegającą akademii, na czele której stoi rektor. Odnotował, że we wszystkich liceach we Francji obowiązuje jednolity program kształcenia uchwalany przez Radę Instrukcji Publicznej w Paryżu, organ, w którym zasiadają przedstawiciele państwa, Kościoła i Akademii Francuskiej (będącej instytucją państwową) oraz profesja scholastyczna. Program kształcenia zatwierdza minister Rady Instrukcji Publicznej, a każde liceum jest zobowiązane do jego realizacji. Porównując program kształcenia chłopców we francuskich i angielskich szkołach, M. Arnold stwierdzał, że poziom wiedzy chłopców z niższych klas w zakresie nauk ścisłych jest stosunkowo niski, jednak lepiej przygotowywani są oni w zakresie nauczania języka ojczystego. W nauce języka ojczystego uczeń francuski ma przewagę nad angielskim, z pewnością uczy się czegoś więcej z języka i literatury francuskiej, uczeń angielski z kolei z języka ojczystego nie uczy się niczego ${ }^{69}$. Elitarne English Public Schools, które wprowadziły znaczące reformy w programie nauczania oraz organizacji szkoły na wzór Rugby School T. Arnolda, kładły ogromny nacisk na wychowanie fizyczne, zajęcia na świeżym powietrzu oraz sporty zespołowe. Te rozwiązania doskonale wpisywały się w realizację koncepcji wychowania gentlemana Johna Locke’a. Dokonując porównania działalności francuskich i angielskich szkół średnich, M. Arnold ze zdziwieniem musiał przyznać, że szkoły francuskie są dużo bardziej zaawansowane w prowadzeniu zajęć z wychowania fizycznego. We French Eton M. Arnold pisał: „He learns and practises gymnastics more than our schoolboys do"70 („On uczy się i uprawia gimnastykę więcej niż nasi uczniowie”, tł A.W.). M. Arnold zwrócił uwagę, że we francuskich szkołach, szczególnie elementarnych, znaczącą rolę odgrywa wychowanie fizyczne uczniów, tak jak to ma miejsce jedynie w najlepszych Public Schools w Anglii.

Jedną z zasług, choć częściowych, M. Arnolda i jego raportów o stanie edukacji było przyjęcie się w Anglii latach 60. XIX wieku terminu „szkoła średnia” (secondary

\footnotetext{
${ }^{68}$ Ibidem, s. 3-4.

${ }^{69}$ M. Arnold, A French Eton, op. cit., s. 11-19.

${ }^{70}$ Ibidem, s. 16.
} 
education $)^{71}$. Słynnym nakazem M. Arnolda było zdanie: „Organise your secondary and your superior instruction” "־2 („Zorganizuj swoje [nauczanie] średnie z lepszym programem", tł. A.W.). Apelował on do angielskiej klasy średniej, aby domagała się od państwa zorganizowania szkół średnich, które będą dawały szansę na lepszą integrację tej warstwy społecznej. Dla M. Arnolda głównym celem edukacji na poziomie szkoły średniej powinno być przede wszystkim dążenie do zaspokojenia potrzeb przedstawicieli angielskiej klasy średniej poprzez organizację odpowiednich typów szkół. Organizacja państwowych szkół średnich, jak argumentował M. Arnold, była istotnym sposobem na zjednoczenie klasy średniej poprzez wyróżniającą się formę edukacji, specjalnie zorganizowaną dla potrzeb i wrażliwości przedstawicieli tejże klasy. Faktem jest, że M. Arnold nalegał, aby każda klasa społeczna miała własne szkoły. Opowiadał się jednoznacznie za rozdziałem poszczególnych typów szkół od klas społecznych ${ }^{73}$. W XIX-wiecznej Anglii dosyć popularnym poglądem było to, że należy zająć się edukacją wszystkich dzieci na poziomie państwa, ale dzieci z ubogich warstw społecznych nie mogą się uczyć w jednej szkole, w jednej ławce szkolnej razem z dziećmi z rodzin arystokratycznych i klasy średniej.

W swojej publikacji A French Eton... M. Arnold pisał, że można wyobrażać sobie zuniformizowane społeczeństwo, w którym jeden system szkolny będzie odpowiedni dla wszystkich jego członków, ale w żadnym kraju europejskim nie ma takiego społeczeństwa. Należy zatem wziąć pod uwagę możliwości danej klasy w zakresie edukacji. Zdaniem M. Arnolda słuszne jest, aby państwo, organizując szkolnictwo, brało pod uwagę nie tylko kondycję danej klasy, ale także oczywiste potrzeby jej członków oraz konkretny cel, do którego zmierzają. Krytycznie oceniał jednak etap rozwoju, w którym znajdowało się wówczas angielskie społeczeństwo. Konkluzja M. Arnolda była taka, że w tym momencie cel, do którego powinna dążyć edukacja w Anglii, jest zdecydowanie inny ${ }^{74}$. Biorąc pod uwagę specyficzne potrzeby klasy średniej M. Arnold proponował, aby ich realizację zapewniały szkoły, które pobierałyby umiarkowane opłaty za naukę, a cieszyłyby się uznaniem za swoją jakość. Szkoły te powinny być regularnie poddawane kontroli w narodowym systemie szkół średnich, regulowanym przez państwo. Potencjalnie, jak podkreślał M. Arnold, takie instytucje mogłyby dać klasie średniej to, co znakomite Public Schools zapewniają wyżzzej klasie: „, $[\ldots]$ the sense of belonging to a great and honourable public institution, which Eton and our three or four great public schools give to our upper class only, and to small fragment broken off from the top of our middle class" przynależności do wielkich i szacownych instytucji publicznych, których Eton i nasze trzy

\footnotetext{
71 R. Anderson, op. cit., s. 98

72 Matthew Arnold, vol. 1, Prose Writings. The Critical Heritage, red. C. Dawson, J. Pfordresher, Routledge, Londyn-Nowy Jork 1979, s. 174.

73 G. McCulloch, Education, op. cit., s. 689.

${ }^{74}$ M. Arnold, A French Eton, op. cit., s. 58-59.

75 Ibidem, s. 65.
} 
lub cztery wielkie Public Schools dają tylko wyższej klasie i niewielkiemu fragmentowi odłamanemu z górnej części naszej klasy średniej”, tł. A.W.). W kwestii realizacji ideału wychowawczego klasy średniej Anglia zdaniem M. Arnolda jest nadal słaba, a Francja, Holandia i Prusy - silne ${ }^{76}$. Stawianie Eton za wzór najlepszej angielskiej instytucji edukacyjnej i wychowawczej w drugiej połowie XIX wieku wynikało z niemal powszechnego przekonania angielskiego społeczeństwa, że kontakt z przedstawicielami arystokracji w Eton stwarza innym uczniom, wywodzącym się z klasy średniej, szanse na przyswojenie sobie „najlepszych cech arystokracji”’7.

Jednym z głównych problemów szkolnictwa, którym zajmował się M. Arnold, było stworzenie kultury klasy przywódczej na potrzeby demokratycznego, przemysłowego państwa ${ }^{78}$. M. Arnold proponował, aby edukacja professional class [klasy profesjonalistów, zaliczanych do klasy średniej - przyp. A.W.] albo też szkoły dla klasy średniej powinny zostać znacznie ulepszone i zorganizowane przez państwo. Nowy system szkolnictwa średniego zliberalizowałby klasę średnią za pomocą tzw. „wzmocnienia kultury", pozwolił na rozwijanie szerokich horyzontów myślowych oraz pomógł lepiej żyć jej członkom dzięki odważniejszym pomysłom ${ }^{79}$.

Ze wszystkich esejów i raportów M. Arnolda wypływa potrzeba zorganizowania powszechnego szkolnictwa, nad którym kontrolę miałoby państwo. Państwo musi się zająć edukacją wszystkich klas społecznych. Ścieżka edukacji od szkoły elementarnej poprzez szkoły specjalne lub uniwersytety powinna prowadzić człowieka do poznania siebie i swojego świata, wedle jego własnych możliwości. Formalna edukacja w szkołach wyższych, wraz z zapewnionym wsparciem w postaci zasiłków finansowych dla najważniejszych potrzeb oraz systematycznymi studiami, spełniać powinna ten niezwykle istotny społecznie cel. Jak konkluduje John F. Kuhn Jr., M. Arnold pisał o liberalnej kulturze, a nie o liberalnej edukacji, co oznaczało, że cel, który przyświecał jego działalności jako inspektora szkolnego i pisarza, był znacznie szerszy aniżeli zwykła reforma edukacji ${ }^{80}$.

Bogaty dorobek M. Arnolda w zakresie komparatystyki edukacyjnej, zanim jeszcze ten obszar badań zaczął być popularny w skali europejskiej i ogólnoświatowej, jednoznacznie świadczy o jego nowatorstwie w podejściu do badań systemów edukacyjnych i kreowaniu polityki oświatowej. Bez wątpienia M. Arnold wyznaczył przyszły kierunek rozwoju pedagogiki porównawczej w Wielkiej Brytanii, głównie poprzez stworzenie wysokich standardów pracy inspektorów szkolnych. Jego liczne publikacje na temat szkolnictwa w Anglii i innych krajach europejskich są znakomitym źródłem wiedzy o historii rozwoju systemów edukacyjnych w Europie.

\footnotetext{
${ }^{76}$ Ibidem, s. 66.

77 A. Gromkowska-Melosik, op. cit., s. 242.

${ }^{78}$ R. Anderson, op. cit., s. 104.

79 G. McCulloch, Cyril Norwood, op. cit., s. 59.

${ }^{80}$ J.F. Kuhn Jr., op. cit., s. 57.
} 


\section{Zakończenie}

M. Arnold uznawany jest przez niektórych wybitnych komparatystów za twórcę angielskiej pedagogiki porównawczej ${ }^{81}$. Faktem jest, że należał on to mainstreamu komparatystów-komentatorów europejskich systemów edukacyjnych w XIX wieku ${ }^{82}$. Bez wątpienia jego zasługi dla rozwoju angielskiego szkolnictwa są bardzo duże. Dzięki swoim wnikliwym raportom stanu oświaty w kontynentalnej Europie mógł wpływać na angielski rząd, wskazywać przede wszystkim na konieczność zorganizowania państwowej, powszechnej edukacji elementarnej, ale także domagać się podniesienia jakości kształcenia w szkołach elementarnych, średnich oraz na uniwersytetach. M. Arnold jednoznacznie zwracał uwagę na sukces reform przeprowadzonych w szkolnictwie pruskim. W samych superlatywach wypowiadał się o koncepcji uniwersytetu Wilhelma von Humbolta. Bardzo dobre zdanie miał również o francuskim szkolnictwie średnim, przekonywał, że angielskie secondary schools wymagają zreformowania. Dostrzegał także potrzebę organizacji profesjonalnego kształcenia nauczycieli. Głównym celem jego pracy jako inspektora szkolnego było nakłonienie rządu do zajęcia się zorganizowaniem powszechnej szkoły elementarnej dla dzieci ze wszystkich klas społecznych. Wszystkie pomysły M. Arnolda dotyczące zmian w organizacji angielskiego szkolnictwa wypływały z jego liberalizmu oraz poszanowania zasad demokracji. Nie bez znaczenia była również droga edukacyjna M. Arnolda - absolwenta renomowanej Rugby School, która swoją świetność zawdzięczała jego ojcu. M. Arnold upatrywał w działalności Public Schools szans na właściwe przygotowanie elit z klasy średniej do przyszłej pracy na rzecz całego kraju. Jak podkreśla J. Miąso, raporty M. Arnolda stanowiły bardzo cenny wkład w proces budowania podstaw angielskiego systemu szkolnego. Do dziś stanowią one niezwykle istotne źródło do badań nad szkolnictwem w Anglii ${ }^{83}$.

M. Arnold, jako absolwent słynnej szkoły średniej, profesor uniwersytecki, krytyk społeczny, ale przede wszystkim najbardziej znany inspektor szkolny, wielokrotnie prezentował swoje poglądy na edukację. Uważał, że odgrywa ona niezwykle ważną rolę w rozwoju nowoczesnego państwa narodowego, w którym funkcjonują różne klasy społeczne. Ważne jest, aby państwo zapewniło wszystkim dzieciom możliwość nauki. Każda angielska klasa społeczna ma jednak inne potrzeby, inne możliwości. Z tego powodu M. Arnold opowiadał się zdecydowanie za organizacją oddzielnych typów szkół dla dzieci i młodzieży z poszczególnych warstw społecznych.

Zapoczątkowane przez M. Arnolda szeroko zakrojone badania komparatystyczne odegrały znaczącą rolę w rozwoju edukacji i nauki w Anglii. Zasługi M. Arnolda dla rozwoju angielskiej oraz europejskiej komparatystki są niepodważalne, czego dowodem

\footnotetext{
${ }^{81}$ P. Nash, op. cit., s. 36.

82 B.A. Rapple, op. cit., s. 2.

83 J. Miąso, op. cit., s. 101.
} 
jest stawianie M. Arnolda przez jednego z najznakomitszych współczesnych amerykańskich komparatystów H.J. Noaha na równi z innymi wybitnymi prekursorami pedagogiki porównawczej, m.in. M.-A. Jullienem de Paris, M.E. Sadlerem, I.L. Kandelem, N. Hansem i P. Rossellò. D. Phillips dodaje, że M. Arnold pozostał prorokiem, którego poglądy miały być bardziej dostrzegane w późniejszych pokoleniach, kiedy stały się one punktem wyjścia do zmian w angielskiej edukacji dla administratorów i decydentów, takich jak M.E. Sadler i R. Morant z Board of Education w Londynie ${ }^{84}$.

M. Arnold, publikując opisy innych europejskich systemów oświatowych, jako inspektor szkolny i jednocześnie akademik, pozwalał sobie na głębokie analizy przeobrażeń społecznych, które miały wówczas miejsce w Europie, wskazywał na ogromną rolę edukacji w rozwoju europejskich społeczeństw. Kontynuatorami jego dzieła byli inni inspektorzy szkolni: T. Darlington i R. Morant, których również zalicza się do grona angielskich prekursorów pedagogiki porównawczej.

\section{Bibliografia}

\section{Źródła}

Arnold M., A French Eton, or a Middle-Class Education and the State, Londyn-Cambridge 1864. Arnold M., A French Eton, or Middle-Class Education and the State, w: Matthew Arnold and the Education of a New Order, red. P. Smith, G. Summerfield, Cambridge 1969.

Arnold M., Culture and Anarchy: an Essay in Political and Social Criticism, Londyn 1869.

Arnold M., Essay in Criticism, Londyn-Cambridge 1865.

Arnold M., Higher Schools and Universities in Germany, Londyn 1874.

Arnold M., Schools and Universities on the Continent, Londyn 1868.

Arnold M., The Popular Education of France: With Notices of that of Holland and Switzerland, Londyn 1861.

Cambridge University Act 1856, legislation.gov.uk, https://www.legislation.gov.uk/ukpga/Vict/1920/88/crossheading/constitution-of-the-university [dostęp: 16.10.2020].

Oxford University Act 1854, legislation.gov.uk, https://www.legislation.gov.uk/ukpga/Vict/1718/81/contents [dostęp: 16.10.2020].

Universities Test Act 1871, The National Archives, http://www.legislation.gov.uk/ukpga/Vict/3435/26 [dostęp: 23.02.2020].

\section{Opracowania}

Anderson R., The Idea of the Secondary School in Nineteenth-century Europe, „Paedagogica Historica" 2004, vol. 40, no. 1-2, s. 93-106.

Armytage W.H.G., A.J. Mundella as Vice-President of the Council, and the Schools Question, 1880-1885, „The English Historical Review” 1948, vol. 63, no. 246, s. 52-82.

${ }^{84}$ D. Phillips, op. cit., s. 59. 
Bush D., Matthew Arnold: A Survey of His Poetry and Prose, Londyn 1971.

Campbell K., Matthew Arnold, Oxford 2008.

Clarke F., Introduction, w: The Educational Thought and Influence of Matthew Arnold, red. W.F. Connell, Londyn 1950.

Connell W.F., The Educational Thought and Influence of Matthew Arnold, Londyn 1950.

Dunford J.E., Her Majesty's Inspectorate of Schools since 1944. Standard Bearers of Turbulent Priests?, Londyn-Nowy Jork 1998.

Epstein E.E., Is Marc-Antoine Jullien de Paris the 'Father' of Comparative Education, „Compare: A Journal of Comparative and International Education" 2017, no. 47, vol. 3, s. 317-331.

Gillard D., Education in England. A history Chapter 5: Towards mass education, http://www.educationengland.org.uk/history/chapter05.html [dostęp: 22.01.2020].

Gillard D., Education in England. A history Chapter 6: A state system of education, http://www. educationengland.org.uk/history/chapter06.html [dostęp: 23.01.2020].

Gromkowska-Melosik A., Elitarne szkolnictwa średnie. Między reprodukcja społeczno-kulturowa a ruchliwościa konkurencyjną, Poznań 2015.

Kuhn J.F. Jr., Some Notes on Matthew Arnold's Though on Education and Culture, „Notre Dame English Journal” 1971, vol. 7, no. 1, s. 52-66.

Loria J., Szkolnictwo w Anglii i jego tradycje, Wrocław-Warszawa-Kraków 1964.

Martín-Sánchez M., Cáceres-Muñoz J., Cardinal Newman: His Importance for Catholic Education, „International Studies in Catholic Education” 2016, vol. 8, no. 1, s. 29-43.

Matthew Arnold, vol. 1, Prose Writings. The Critical Heritage, red. C. Dawson, J. Pfordresher, Londyn-Nowy Jork 1979.

McCulloch G., Cyril Norwood and the English Tradition of Education, „Oxford Review of Education" 2006, vol. 32, no. 1, s. 55-69.

McCulloch G., Education and the Middle Classes: The Case of the English Grammar Schools 1868-1944, „History of Education” 2006, vol. 35, no. 6, s. 687-704.

Miąso J., Szkolnictwo w XIX-wiecznej Europie i początki pedagogiki porównawczej w Anglii, „Rozprawy z Dziejów Oświaty” 2009, t. 48, s. 85-146.

Nash P., Arnold, Matthew (1822-1888), w: Philosophy of Education. An Encyclopedia, red. J.J. Chambliss, New York 1996, s. 36-37.

Noah H.J., Fast-Fish and Loose-Fish in Comparative Education, „Comparative Education Review" 1976, vol. 18, no. 3, s. 341-347.

Phillips D., Beyond Traveller's Tales: Some Nineteenth-Century British Commentators on Education in Germany, „Oxford Review of Education” 2000, vol. 26, no. 1, s. 49-62.

Rapple B.A., Matthew Arnold and English Education. The Poet's Pioneering Advocacy in Middle Class Instruction, North Carolina 2017.

Sandiford P., Szkolnictwo angielskie, thum. W. Gumplowicz, Warszawa 1927.

Stone D.D., Communications with the Future: Matthew Arnold in Dialogue: Henry James, Charles-Augustin Sainte-Beuve, Ernest Renan, Michel Foucault, Friedrich Nietzsche, Hans-George Gadamer, William James, Richard Rorty, John Dewey, Michigan 1997.

Szacki J., Historia myśli socjologicznej, Warszawa 2002.

Willey B., Matthew Arnold, w: Encyclopaedia Britannica, https://www.britannica.com/biography/ Matthew-Arnold [dostęp: 18.02.2020].

Włoch A., The Development of Teachers Education in England in the $19^{\text {th }}$ Century, „Przegląd Historyczno-Oświatowy" 2019, nr 1-2, s. 60-75. 